\title{
Isolation of Plasma Proteins from Bovine Blood by Cold Ethanol Precipitation and Anion Exchange Chromatography
}

\author{
Patricia Adamma Ekwumemgbo, ${ }^{*}{ }^{*}$ James Adagadzu Kagbu ${ }^{1}$, Andrew \\ Jonathan Nok ${ }^{2}$, Israel Kehinde Omoniyi ${ }^{3}$, Paul Ocheme Ameh ${ }^{1}$ and \\ Nathaniel Oladunni ${ }^{1}$ \\ ${ }^{1}$ Department of Chemistry, Ahmadu Bello University, Zaria. ${ }^{2}$ Department of Biochemistry, Ahmadu \\ Bello University, Zaria. ${ }^{3}$ Ahmadu Bello University, School of Remedial Studies Funtua \\ e-mail:pat_adamma@yahoo.com
}

\begin{abstract}
Plasma (100.00 $\mathrm{ml})$ obtained from bovine blood by centrifugation was fractionated into seven precipitates by cold ethanol precipitation. The yield (amount) of proteins in the precipitates calculated from the standard curve of BSA was $1160.83 \mathrm{mg}, 806.57 \mathrm{mg}$, $1149.94 \mathrm{mg}, 8.79 \mathrm{mg}, 19.88 \mathrm{mg}, 21.98 \mathrm{mg}$, and $13.97 \mathrm{mg}$ respectively, while the total amount of protein obtained was $3180.00 \mathrm{mg}$. The precipitates were fractionated into 25 fractions each by Anion Exchange Chromatography (AEC) and the amount of protein in each fraction was obtained by Bradford protein assay. SDS-PAGE analysis was performed on the fractions with proteins and their estimated molecular weights were obtained with the aid of the molecular weight marker. The result indicated that cold ethanol precipitation and anion exchange chromatographic techniques are valuable tools for the purification of bovine blood to obtain high grade $\alpha, \beta$ and $\gamma$-fibrinogen, IgM ( $\mu$-globulin), IgG $(\gamma-$ globulin), alpha ( $\alpha$-globulin), $\beta$-globulin (E-globulin) and albumin.
\end{abstract}

Keywords: Plasma, chromatography, electrophoresis, albumin, fibrinogen, globulin.

\section{Introduction}

Food and agro-allied industries usually produce large amount of wastes and where adequate disposal systems are unavailable, such wastes create environmental problems. In the meat industry the slaughtering process is the largest contributor to liquid waste. Among the liquid waste (by-product) from the slaughtering process, ${ }^{1}$ blood is one of the most problematic due to the great amount and high pollutant load ${ }^{2}$. Blood effluent increases nitrogen, phosphorus and biochemical oxygen demand of any receiving water body potentially leading to eutrophication ${ }^{3}$. In Nigeria many slaughter houses dispose their waste directly into streams or rivers and use water from the same source to wash slaughtered meat.

"Corresponding author 
Blood comprises of plasma which is basically composed of proteins, water and a variety of salts and low molecular weight compounds ${ }^{4}$. Plasma is a complex body fluid that contains various proteins ranging in concentration over at least nine orders of magnitude ${ }^{5}$. Plasma proteins have potential economic values, it is therefore necessary to consider the recovering of proteins in the blood since treatment of this blood will help minimize environmental pollution by blood from the slaughterhouses ${ }^{6}$. Obviously, this is not a solution for the huge amount of blood produced, but it is a way to obtain economic benefit from a waste product ${ }^{4}$.

Fractionation of blood proteins from blood in most cases entails separation of the plasma which is the liquid fraction of the blood from the cellular fraction by centrifugation ${ }^{6}$. There are various protein fractionation methods ${ }^{7,8}$ which are based on differential solubility or differential interaction with physical parameters ${ }^{7}$. The methods based on differential solubility include alcohol fractionation ${ }^{4,9}$ and the use of polyethylene glycol $^{8}$ which constitutes the major methods of differential solubility use for large scale protein purification.

Several attempts have been made to isolate proteins from matrices for instance isolation of albumin from bovine plasma by liquid chromatography and polymerisation of the isolated sample for use in immunohematology by the removal of haemoglobin, fibrinogen, globulin and nonspecific hemagglutinin ${ }^{10}$. Salt fractionation of plasma proteins and identification of protein fractions ${ }^{11}$. Coupling process for plasma protein fractionation using ethanol precipitation and ion exchange chromatography ${ }^{4}$. Isolation of globulin from bovine serum on Sephadex G100 gel chromatographic column ${ }^{12}$ and isolated of albumin from bovine serum using Sephadex G100 gel chromatographic column ${ }^{13}$. The objective of this work is to fractionate and purify major plasma protein fractions in bovine blood by cold ethanol precipitation and anion exchange chromatographic (AEC) technique.

\section{Experimental Methods}

\section{Materials}

Thermostated stirrer, UV-Visible Spectrophotometer (Jenway 64050), crisson 2000 pH meter, peristaltic pressure pump, centrifuge apparatus (Baird and Tatlock Auto Bench), millipore glass column, fraction collectors, electrophoresis power supply (EPS 601) Amersham Pharmacia biotech, bovine serum albumin (BSA), Q-sepharose 4B, sodium citrate, absolute ethanol, sodium potassium tartarate, monosodium dihydrogen phosphate, disodium hydrogen phosphate, hydrated copper sulphate, acrylamide-bis acrylamide stock (acrylamide and bisacrylamide), Biuret reagent, Bradford reagent, coomassie brilliant blue (CBB) solution ( $\overline{\mathrm{CBB}}$, methanol, glacial acetic acid), running gel (bis/acrylamide stock, tris $\mathrm{HCl}$, SDS, ammonium persulphate, N, N, N', N'-tetramethylethylenediamine (TEMED)), sodium dodecyl sulphate (SDS), tris-glycine buffer (amino acetic acid, tris-base, SDS), trishydrochloric acid (tris base, $\mathrm{HCl}$ ), 2-mercaptoethanol. All reagents used were AR grade and double distilled water was used for their preparation. 


\section{Plasma extraction from bovine blood}

Bovine blood was collected from the slaughter house in Zongo, Zaria in Kaduna State, Nigeria from the vein of a six year old female bovine as it was being bled. From previous history the bovine had no record of any kind of infection. An anticoagulant, sodium citrate $2.0 \%(\mathrm{w} / \mathrm{v})$ was rapidly added at a concentration of $1.0 \%(\mathrm{w} / \mathrm{v})$ to prevent the blood from clotting. The sample was then kept on ice to maintain $4^{\circ} \mathrm{C}$ temperature. The blood sample was centrifuged at $6000 \mathrm{~g}$ for 60 minutes to separate the plasma $(60.0 \%$ of the total blood volume) from the cells ( $40.0 \%$ of the total blood volume). The supernatant obtained was further centrifuged for 30 minutes at $1500 \mathrm{~g}$ to separate the fat from the plasma. The supernatant obtained (plasma) was stored in the deep freezer at a temperature of $4^{\circ} \mathrm{C}$ until use for maximum period of $30 \mathrm{~h}^{4}$.

\section{Protein precipitation from plasma}

Exactly $100.00 \mathrm{ml}$ of the plasma obtained was diluted to $50.0 \%$ with cold distilled water to obtain a final volume of $200.00 \mathrm{ml}$. Ethanol (absolute) was added until the desired concentrations of $25.0 \%$ was obtained and the $\mathrm{pH}$ adjusted appropriately with $\mathrm{HCl}$ and phosphate buffer added to keep the ionic strength of the composition constant. The mixture was allowed to stand on ice in a deep freezer for 30 minutes after which it was centrifuged for 10 minutes at $130 \mathrm{~g}^{14}$. The supernatant was decanted and the precipitate formed collected. The precipitation steps and conditions employed to obtain PPT I, PPT II, PPT III, PPT IV, PPT V, PPT VI and PPT VII are shown in the flow diagram in Fig. 1. The precipitates obtained were re-dissolved in $5.00 \mathrm{ml}$ of $0.20 \mathrm{M}$ phosphate buffer at $\mathrm{pH} 6.8^{4}$.

\section{Determination of amount of protein in precipitates}

The amount of protein in precipitate was determined by Biuret protein assay. Standard calibration curve was prepared by reading the absorbance of $1.00-10.00 \mathrm{mg} / \mathrm{ml}$ standard concentrations of bovine serum albumin (BSA) with the UV-Visible Spectrophotometer. The obtained absorbance values were plotted against concentrations which gave a linear standard calibration curve. Sample aliquots $(0.50 \mathrm{ml})$ of every test sample was placed in a test tube containing $2.50 \mathrm{ml}$ biuret reagent and incubated for 30 minutes. Absorbance of the content of the test tube was measured at $540 \mathrm{~nm}$ with the UV-Visible Spectrophotometer. From the linear curve obtained, the concentration of protein in every precipitate was calculated according to the standard curve of BSA.

\section{Fractionation of precipitates}

Glass wool was placed at the bottom of the millipore glass column to support the resin. The resin slurry was poured into the column and allowed to settle by gravity to a bed height of $2.50 \mathrm{~cm}^{15}$. The column was equilibrated using $200 \mathrm{mM}$ phosphate buffer solution of $\mathrm{pH}$ 6.8. The column was connected to a peristaltic pressure pump to exact pressure of about $200,000 \mathrm{~N} / \mathrm{m}^{2}$ to aid in the elution of fractions.

Sterilized syringe was used to aspirate and inject $0.50 \mathrm{ml}$ of each precipitate solution obtained from ethanol precipitation into the packed column immediately after equilibrating the column. The solvents used for elution were phosphate buffer $(\mathrm{pH} 6.8), 50.00 \mathrm{mM}$, $250.00 \mathrm{mM}, 500.00 \mathrm{mM}$ and $750.00 \mathrm{mM}$ sodium chloride solution prepared in phosphate buffer (pH 6.8) respectively ${ }^{16}$. 


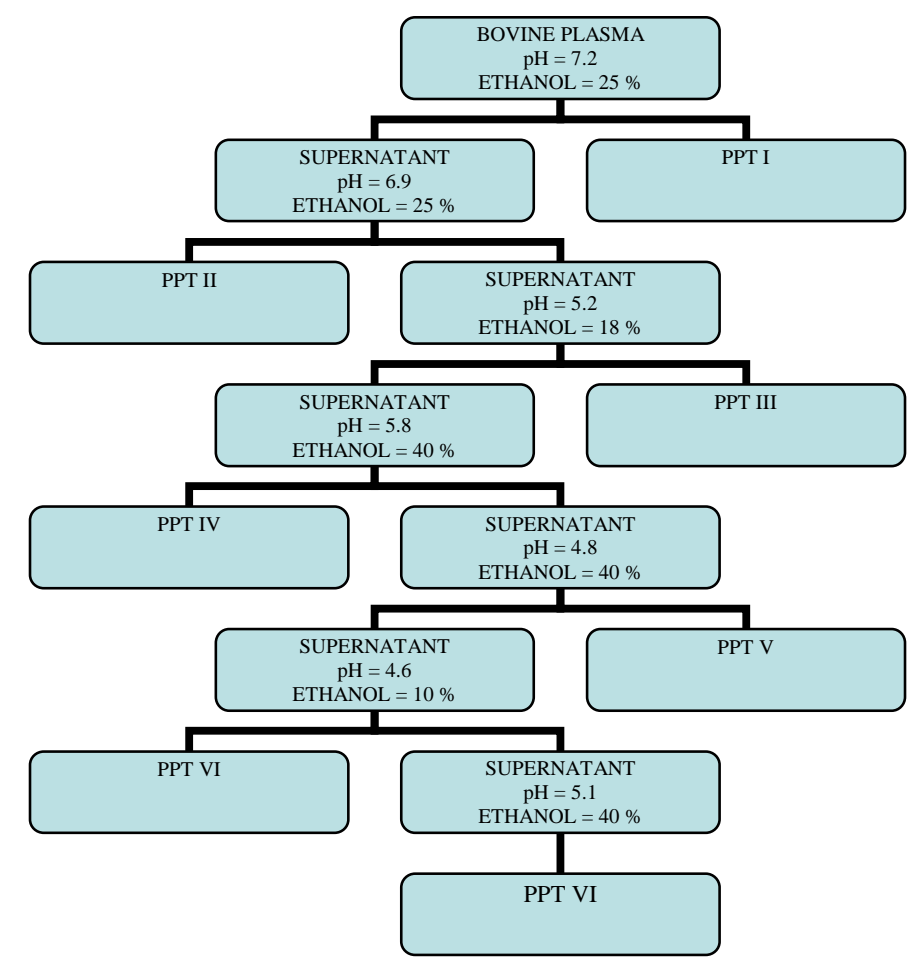

Figure 1: Fractionation of bovine plasma by cold ethanol precipitation

Protein components of the precipitates were separated with the equilibrated column. 25 fractions of $1.00 \mathrm{ml}$ each were collected for each precipitate. Fraction 1 was the out flow from column when sample was loaded. Phosphate buffer solution ( $\mathrm{pH}$ 6.8) was used to elute fraction 2, 3, 4, $50.00 \mathrm{mM}$ sodium chloride solution was used to elute fraction 5, 6, 7, $8 ; 250.00 \mathrm{mM}$ sodium chloride solution was used to elute fraction $9,10,11,12,13,14,15$; $500.00 \mathrm{mM}$ sodium chloride solution was used to elute fraction 16, 17, 18, 19, 20 and $750.00 \mathrm{mM}$ sodium chloride solution was used to elute fraction 21, 22, 23, 24 and 25.

\section{Determination of amount of protein in fractions from AEC}

The amount of protein in fractions obtained from AEC was determined by Bradford assay. Standard concentrations $(0.10$ to $1.00 \mathrm{mg} / \mathrm{ml})$ of bovine serum albumin (BSA) was prepared and placed into test tubes; the volumes were adjusted to $2.00 \mathrm{ml}$ with phosphate buffer ( $\mathrm{pH} 6.8$ ); $5.00 \mathrm{ml}$ of Bradford reagent was added to the content of the test tube; mixed thoroughly by inversion and the absorbance measured respectively at $595 \mathrm{~nm}$ with the colorimeter between 5 minutes and 60 minutes in $4.00 \mathrm{ml}$ capacity cuvettes against a reagent blank prepared with $1.00 \mathrm{ml}$ of the phosphate buffer $(\mathrm{pH} 6.8)$ and $5.00 \mathrm{ml}$ of Bradford reagent. The obtained absorbance values were plotted against concentrations which gave a linear standard calibration curve. From the linear curve obtained, the amount of protein in every fraction was calculated according to the Bradford assay standard curve of bovine serum albumin (BSA) ${ }^{17}$. 


\section{SDS-PAGE of protein fractions from AEC}

Sodium dodecyl sulphate polyacrylamide gel electrophoresis (SDS-PAGE) of protein fractions from AEC was carried out by treating $50.00 \mu \mathrm{l}$ of the fractions with $50.00 \mu \mathrm{l}$ of tris glycine buffer, one drop of mercaptoethanol, one drop of bromophenol blue and one drop of glycerol added to increase the density of the sample. This composition was placed in boiling water for 5 minutes to denature the proteins; $20.00 \mu \mathrm{l}$ of the test samples were loaded into sample wells and electrophoresis was performed at 160 volt for one hour using the running gel. On completion of electrophoresis, gels were removed and staining procedure was carried out with coomassie brilliant blue (R-250) for 3 hours. After staining, gels were destained with $10.0 \%$ ethanoic acid until a clear blue protein bands were observed against a clear white background and the bands photographed. The molecular weight marker was used as the standard.

\section{Results and Discussion}

\section{Amount of proteins in precipitates}

The protein concentrations in PPT I, PPT II, PPT III, PPT IV, PPT V, PPT VI and PPT VII were 24.70, 29.83, 0.08, 0.65, 1.33, 2.20 and $1.27 \mathrm{mg} / \mathrm{ml}$, respectively. The amount in each precipitate was $1160.83 \mathrm{mg}, 806.57 \mathrm{mg}, 1149.94 \mathrm{mg}, 8.79 \mathrm{mg}, 19.88 \mathrm{mg}, 21.98 \mathrm{mg}$ and $13.97 \mathrm{mg}$, respectively, while the total amount of proteins obtained was $3181.96 \mathrm{mg}$ as presented in Table 1. PPT I has the highest protein yield while PPT IV has the lowest protein yield. The total percentage of protein obtained in PPT I, PPT II and PPT III was $97.97 \%$ while $2.03 \%$ was obtained in PPT IV, PPT V, PPT VI and PPT VII which is an indication that most of the proteins in the plasma could be obtained in the first three steps of the fractionation procedure employed.

Table 1: Amount of proteins in precipitates

\begin{tabular}{|lllll|}
\hline Samples & $\begin{array}{c}\text { Concentration } \\
\text { in } \mathrm{mg} / \mathrm{ml}\end{array}$ & $\begin{array}{c}\text { Total volume } \\
\text { of PPT }\left(\mathrm{cm}^{3}\right)\end{array}$ & $\begin{array}{c}\text { Amount of protein } \\
\text { in PPT }(\mathrm{mg})\end{array}$ & $\begin{array}{c}\text { Percentage of } \\
\text { protein in PPT }\end{array}$ \\
\hline PPT I & 24.6984 & 47.00 & 1160.83 & $36.48 \%$ \\
PPT II & 29.8730 & 27.00 & 806.57 & $25.35 \%$ \\
PPT III & 30.0784 & 37.00 & 1149.94 & $36.14 \%$ \\
PPT IV & 0.6508 & 13.50 & 8.79 & $0.28 \%$ \\
PPT V & 1.3254 & 15.00 & 19.88 & $0.62 \%$ \\
PPT VI & 2.1984 & 10.00 & 21.98 & $0.69 \%$ \\
PPT VII & 1.2699 & 11.00 & 13.97 & $0.44 \%$ \\
& Total amount of proteins obtained $=3181.96 \mathrm{mg}$ & \\
\hline
\end{tabular}

\section{Anion exchange chromatogram of precipitates}

The amount of proteins recovered from AEC of PPT I, PPT II, PPT III, PPT IV, PPT V, PPT VI and PPT VII was $12.302 \mathrm{mg}, 12.298 \mathrm{mg}, 14.938 \mathrm{mg}, 0.644 \mathrm{mg}, 1.302 \mathrm{mg}, 2.156$ $\mathrm{mg}$ and $1.256 \mathrm{mg}$, respectively, which is $99.60 \%, 82.30 \%, 99.30 \%, 98.90 \%, 98.30 \%$, $98.10 \%$ and $98.90 \%$ recovery, respectively, as presented in Table 2. The plots of 
absorbance against fractions of each precipitate are depicted in Figs 2, 3, 4, 5, 6, 7 and 8 in which the major peaks correspond to fractions with protein content.

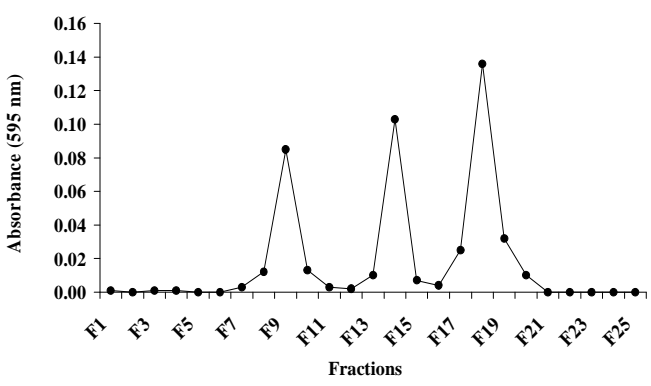

Figure 2 Anion Exchange Chromatogram of PPT I.

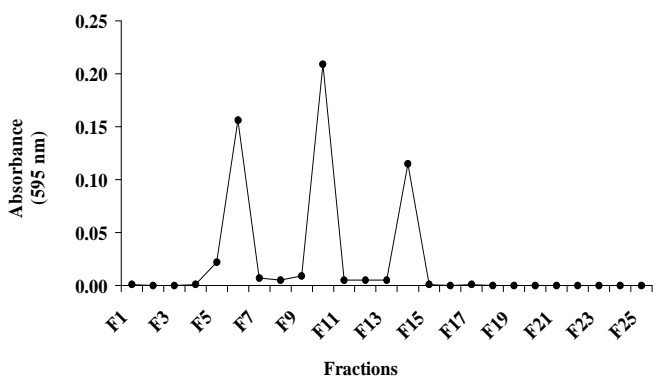

Figure 4: Anion Exchange Chromatogram of PPT III.

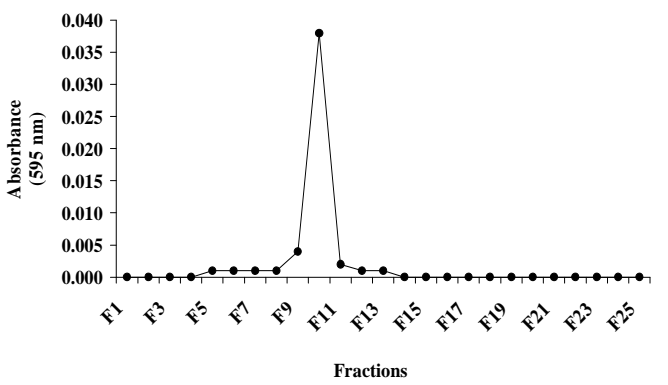

Figure 6: Anion Exchange Chromatogram of PPT V.

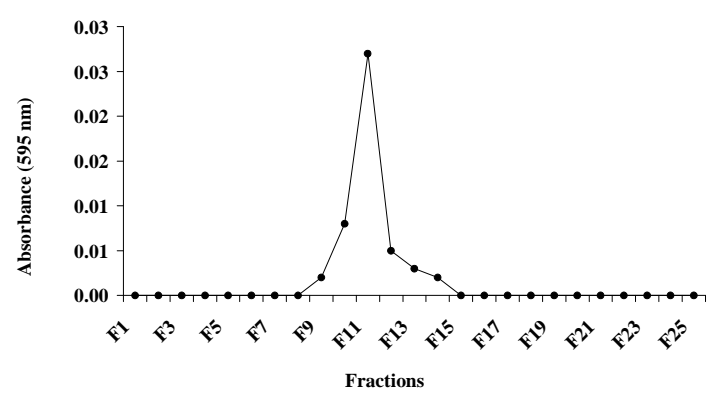

Figure 8: Anion Exchange Chromatogram of PPT VII.

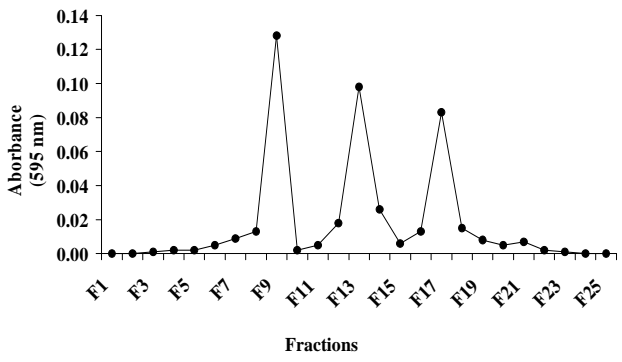

Figure 3: Anion Exchange Chromatogram of PPT II.

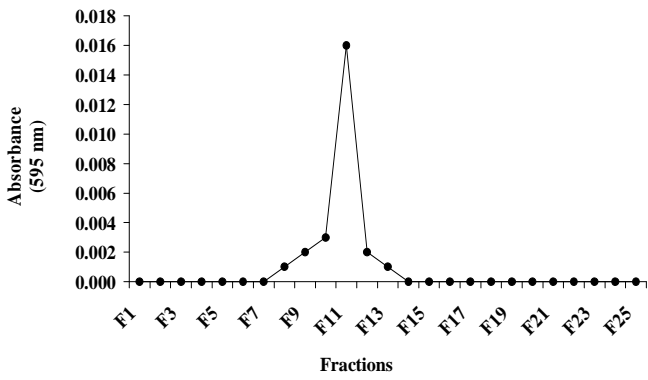

Figure 5: Anion Exchange Chromatogram of PPT IV.

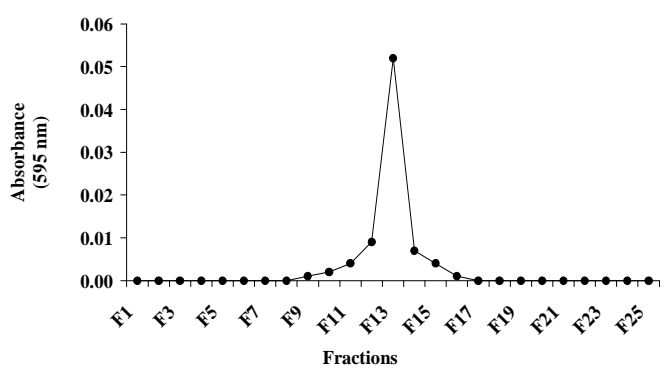

Figure 7: Anion Exchange Chromatogram of PPT VI.

Figures 2-8: Major peaks correspond to fractions with protein content for PPT I, PPT II, PPT III, PPT IV, PPT V, PPT VI and PPT VII. 
Table 2: Percentage recovery of protein in precipitates (PPT)

\begin{tabular}{|lllll|}
\hline $\begin{array}{l}\text { Precipitate } \\
\text { (PPT) }\end{array}$ & $\begin{array}{l}\text { Amount loaded } \\
\text { on column }\end{array}$ & $\begin{array}{l}\text { Amount in 0.50 } \\
\text { ml of fraction }\end{array}$ & $\begin{array}{l}\text { Amount in 1.00 } \\
\text { ml of fraction }\end{array}$ & $\begin{array}{l}\text { Percentage } \\
\text { (\%) recovery }\end{array}$ \\
\hline PPT I & 12.349 & 6.151 & 12.302 & $99.6 \%$ \\
PPT II & 14.936 & 6.149 & 12.298 & $82.3 \%$ \\
PPT III & 15.039 & 7.469 & 14.938 & $99.3 \%$ \\
PPT IV & 0.651 & 0.322 & 0.644 & $98.9 \%$ \\
PPT V & 1.325 & 0.651 & 1.302 & $98.3 \%$ \\
PPT VI & 2.198 & 1.078 & 2.156 & $98.1 \%$ \\
PPT VII & 1.270 & 0.628 & 1.256 & $98.9 \%$ \\
\hline
\end{tabular}

SDS-PAGE of fractions and molecular weight calculation

SDS-PAGE was performed on every fraction from AEC with conspicuous peak signifying high plasma protein component and the molecular weight estimated by comparing the migration of the proteins to standards of known weights (molecular weight marker) which is the plot of the log of the molecular weights of proteins in the standard against the relative mobility. The relative mobility $\left(\mathrm{R}_{\mathrm{f}}\right)$ was calculated by dividing the distance the protein migrated by the total length of the gel or dye front. The molecular weights and mobility of molecular weight marker (standard) are presented in Table 3.

Table 3: Mobility of fractions and the estimated molecular weights

\begin{tabular}{|llllllc|}
\hline $\begin{array}{c}\text { Precipitate } \\
\text { (PPT) }\end{array}$ & Fractions & $\begin{array}{c}\text { Length of } \\
\text { gel }(\mathbf{m m})\end{array}$ & $\begin{array}{c}\text { Mobility of } \\
\text { fraction } \\
\text { (mm) }\end{array}$ & $\begin{array}{c}\text { Relative } \\
\text { mobility } \\
\left(\mathbf{R}_{\mathbf{f}}\right)\end{array}$ & $\begin{array}{c}\text { Log } \\
\text { molecular } \\
\text { weight }\end{array}$ & $\begin{array}{c}\text { Molecular } \\
\text { weight } \\
(\mathbf{D a})\end{array}$ \\
\hline PPT I & F9 & 125 & 41 & 0.328 & 4.80 & 63,100 \\
& F14 & 90 & 34 & 0.378 & 4.75 & 56,200 \\
& F18 & 121 & 56 & 0.463 & 4.67 & 47,000 \\
PPT II & F9 & 107 & 34 & 0.318 & 4.83 & 68,000 \\
& F13 & 106 & 36 & 0.340 & 4.79 & 64,600 \\
& F17 & 119 & 33 & 0.277 & 4.86 & 74,100 \\
PPT III & F6 & 98 & 32 & 0.327 & 4.83 & 68,000 \\
& F10 & 95 & 31 & 0.326 & 4.81 & 64,600 \\
PPT IV & F14 & 118 & 33 & 0.280 & 4.85 & 70,800 \\
PPT V & F11 & 106 & 35 & 0.330 & 4.80 & 63,100 \\
PPT VI & F13 & 104 & 37 & 0.356 & 4.78 & 60,300 \\
PPT VII & F13 & 106 & 36 & 0.340 & 4.79 & 62,000 \\
\hline
\end{tabular}

\section{Molecular weight of proteins in fractions}

The molecular weights of plasma proteins estimated in PPT I (fractions 9, 14 and 18) were $63,100 \mathrm{Da}, 56,200 \mathrm{Da}$ and 47,000 $\mathrm{Da}$, respectively, which correspond to three chains $\alpha, \beta$ and $\gamma$-fibrinogen molecules joined by disulphide bonds as depicted in plate I lane 2, 3 and 4 respectively, while lane 1 is the standard (molecular weight marker) ${ }^{4}$. In PPT II, the molecular weights of fractions 9, 13 and 17 were 68,000 Da, 64,600 Da and 70,100 Da which correspond to IgM ( $\mu$-globulin), ${ }^{18} \operatorname{IgG}\left(\gamma\right.$-globulin) and $\beta$-globulin (E-globulin) ${ }^{4}$, as depicted in plate II lane 2, 3 and 4, respectively. In PPT III, molecular weights of fractions 
6, 10 and 14 were 68,000 Da, 64,600 Da and 70,800 Da which correspond to $\operatorname{IgM}(\mu$ globulin), ${ }^{18}$ alpha globulin ( $\alpha$-globulin) and albumin as observed in plate III lane 2,3 and 4 respectively ${ }^{4}$. In PPT IV, V, VI and VII, the molecular weights of fraction 11, 10, 13 and 11 were $63,100 \mathrm{Da}, 64,300 \mathrm{Da}, 62,000 \mathrm{Da}$ and 60,300 $\mathrm{Da}$ which is albumin as shown in plates IV, V, VI and VII, respectively.

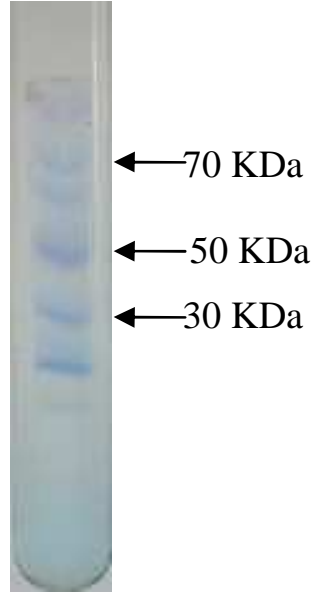

Lane 1

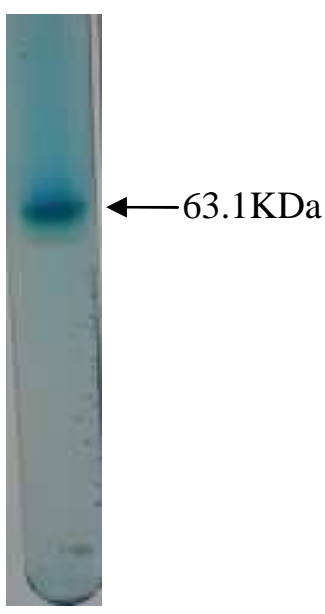

Lane 2

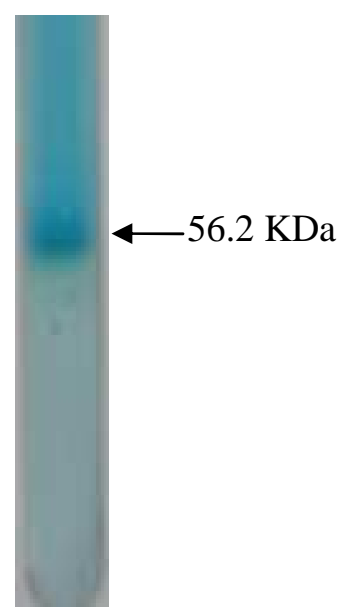

Lane 3

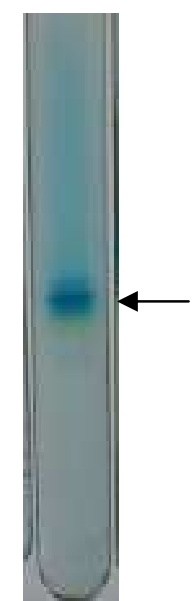

Lane 4

Plate I: Electrophoregram of fractions from PPT I

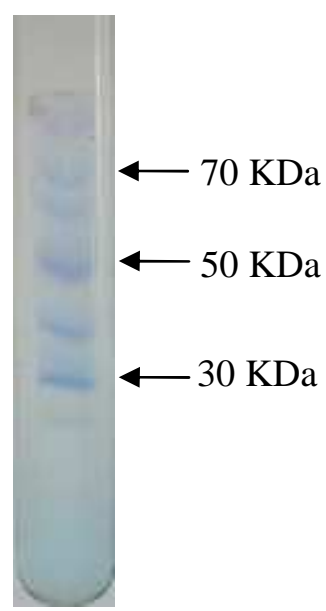

Lane 1

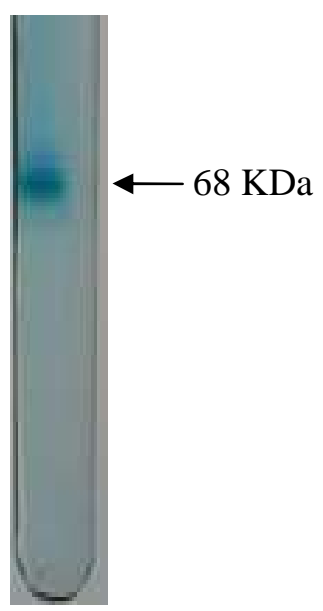

Lane 2

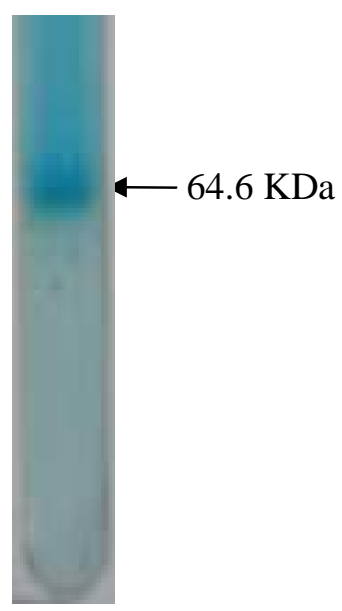

Lane 3

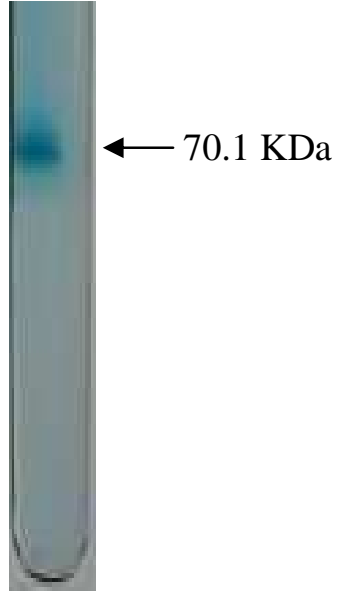

Lane 4

Plate II: Electrophoregram of fractions from PPT II 
J. Nepal Chem. Soc., vol. 26, 2010
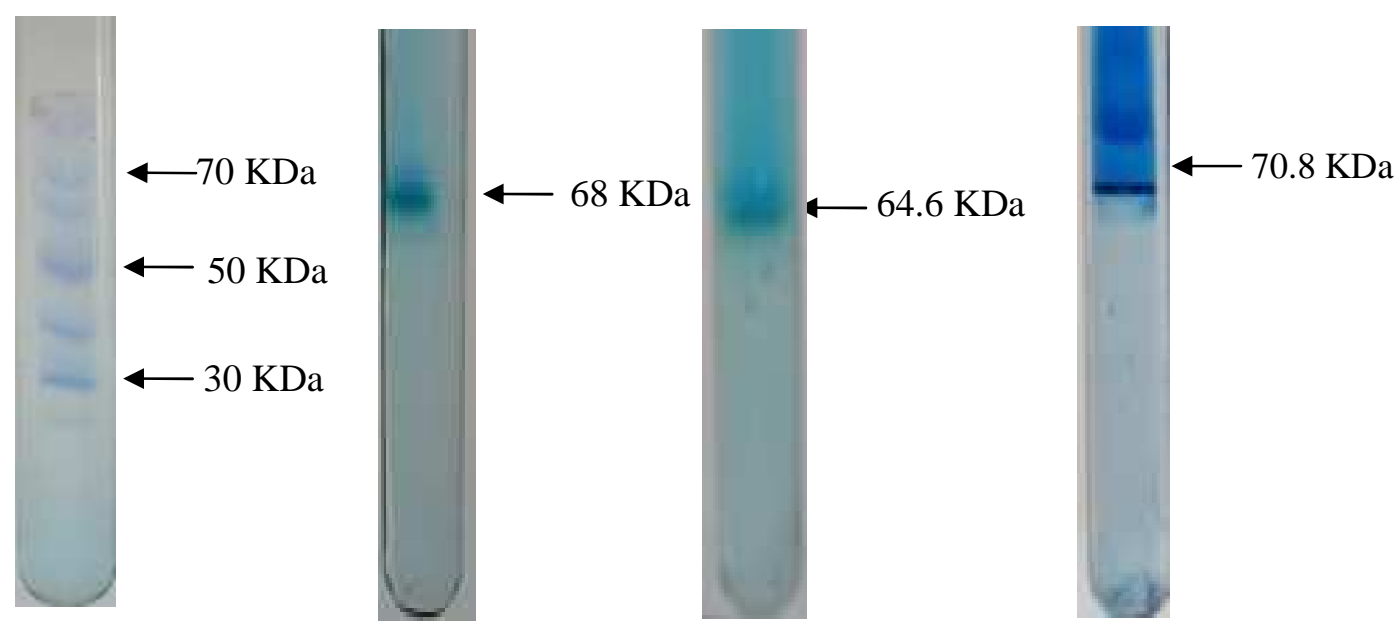

Lane 1

Lane 2

Lane 3

Lane 4

Plate III: Electrophoregram of fractions from PPT III

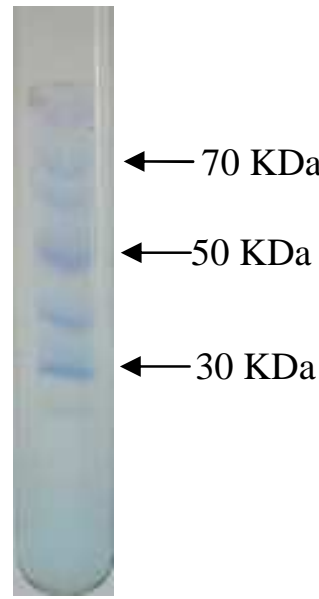

Lane 1

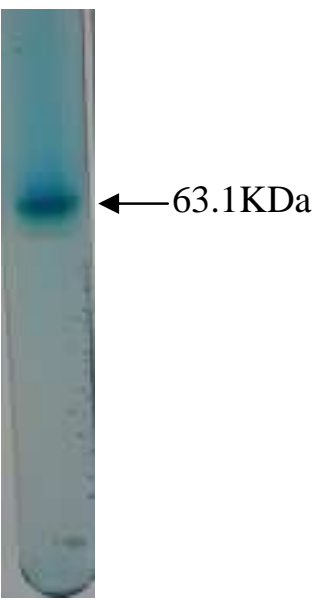

Lane 2

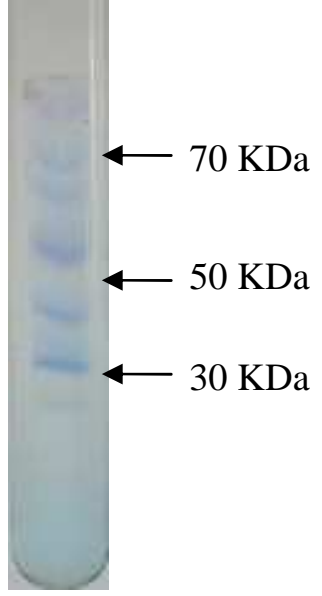

Lane 1

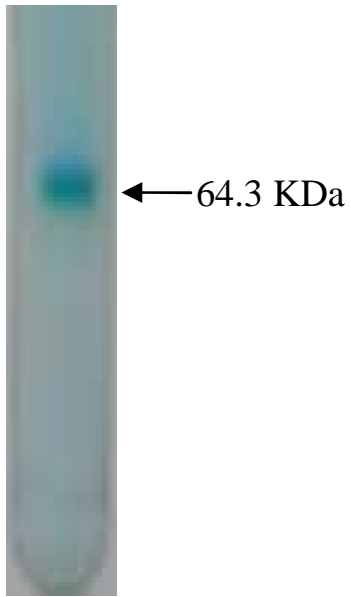

Lane 2

Plate IV: Electrophoregram of fraction from Plate $\boldsymbol{V}$ : Electrophoregram of fraction from PPT IV PPT V 


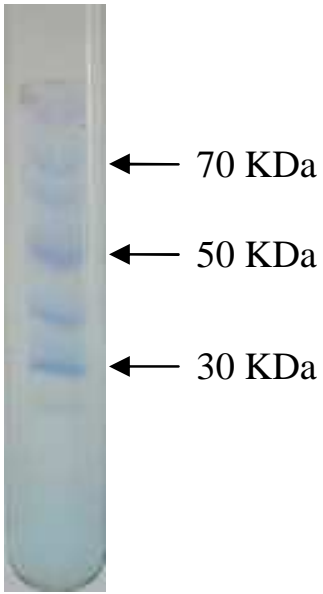

Lane 1

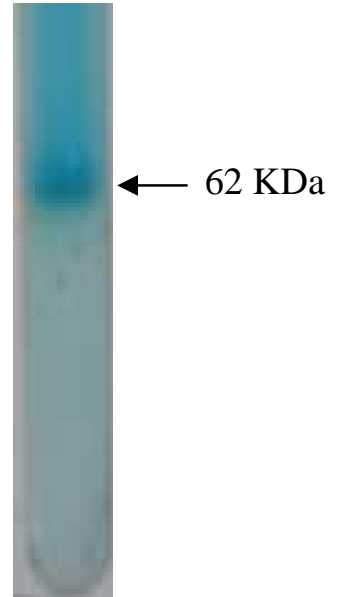

Lane 2

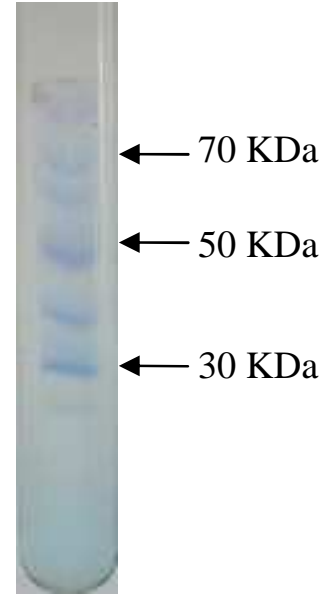

Lane 1

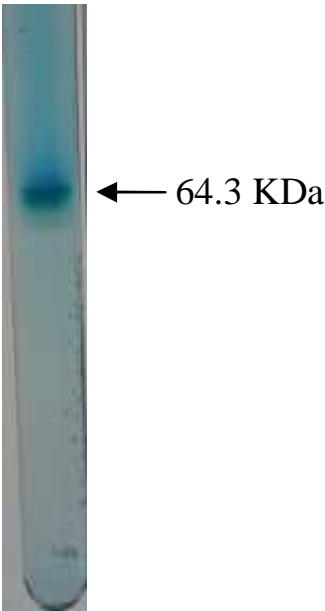

Lane 2

Plate VI: Electrophoregram of fraction from PPT VI

Plate VII: Electrophoregram of fraction from PPT VII

\section{Conclusions}

Cold ethanol precipitation and AEC are valuable tools for the purification of bovine blood to obtain high grade $\alpha, \beta$ and $\gamma$-fibrinogen, $\operatorname{IgM}$ ( $\mu$-globulin), IgG ( $\gamma$-globulin) alpha $(\alpha-$ globulin), $\beta$-globulin (E-globulin) and albumin. These proteins are extensively employed for therapeutic and diagnostic purposes. The advantage of this combined process (Cold ethanol precipitation and $\mathrm{AEC}$ ) is that, depending on the required purity of the proteins, either fractionation with ethanol alone or both steps (fractionation and AEC) may be employed.

\section{Acknowledgements}

The authors are thankful to Prof. T. Hanawa of the Institute of Biomaterials and Bioengineering Tokyo Medical and Dental University, Tokyo, Japan through whom the QSepharose 4B and BSA used for this research were obtained.

\section{References}

1. H. W. Ockerman and C. I. Hansen, in Animal By-product Processing and Utilization, Florida, USA. CRC Press, 2000

2. P. D. Hoyo, F. Moure and M. Diaz, Meat Sci., 2007, 76, 8

3. M. O. Benka-Coker and O. O. Ojior, Biores. Technol., 1995, 52, 7

4. F. Moure, M. Rendueles and M. Diaz, Meat Sci., 2003, 64, 10 
5. J. N. Adkins, S. M. Varnum, K. J. Auberry, R. J. Moore, N. H. Angell, R. D. Smith, D. L. Springer, and J. G. Pounds, Molecular and Cellular Proteomics, 2002, 1, 9

6. M. Rendueles, F. Moure, A. Fernandez, and M. Diaz, Res. Envir. Biotechnol., 1996, 1, 14

7. J. M. Curling, in Methods of Plasma Protein Fractionation, London. Academic Press, 1980, p. 80

8. Y. Z. Lee, T. Aishima, S. Nakei and J. S. Sim, J. Agri. Food Chem., 1987, 35, 5

9. E. J. Cohn, L. E.Strong, N. L. Hughes, D. J. Mulford, J. N. Asworth, M. Melin and H. L. Taylor, J. Amer. Chem. Soc., 1987, 68, p. 459

10. K. Tanaka, E. Sawatani, E. M. Shigueoka, G. A. Dias, H. C. Nakao and F. Arashiro, Braz. J. Med. Biol. Res., 2001, 34(8), 7

11. C. C. Spadaro, A. I. Assis-Pandochi, Y. M. Lucisano-Valim and Z. Rothschild, The International Union of Biochemistry and Molecular Biology, 2003, 31, 4

12. S. A. Hamzat, in Collection of Globulin from Bovine Serum using Gel Filtration Technique, Undergraduate project, Ahmadu Bello University, Zaria, 2005, p. 44

13. R. T. Ajoyous, in Isolation of Albumin from Bovine Serum, Undergraduate project, Ahmadu Bello University, Zaria, 2005, p. 47

14. S. Englard, and S. Seifter, in Precipitation Techniques, London Academic Press, 1990, p. 182

15. E. Boschetti, L. Gureeier, P. Girot, J. Horvath, J. Chromat., 1995, 664, 7

16. V. M. Tischenko, V. P. Zav'yalow, G. A. Medgyesi, S. A.Potekhin and P. L. Privalov, Eur. J. Biochem. 1998, 126, 5

17. M. M. Bradford, Analytical Biochemistry, 1976, 72, 7

18. I. Roitt, J. Brostoff, and D. Male, in Immunology, London, Gower Medical Publishing, 1991 